\title{
AN ANALYSIS OF THE HUNGARIAN UNSECURED INTERBANK MARKET BEFORE AND AFTER THE COVID-19 PANDEMIC
}

\author{
Ákos Zsolt Bodnár
}

\begin{abstract}
In this article, I examine the structure of the Hungarian unsecured interbank forint market and the change of its network in time between 2019 and 2020, the years before and after the pandemic. I introduce the general characteristics of the market, such as turnover and interest rate, as well as the basic network and structural features. It can be established that, following the COVID-19 pandemic, the unsecured interbank turnover has increased by nearly $30 \%$, which is partly attributable to the liquidity-providing measures taken by the central bank. In March, there was a spike in the interest weighed according to daily turnover, and it had higher level and volatility for the rest of the year 2020 than in 2019. Compared with the period following the bankruptcy of Lehman Brothers, the shock resistance of the unsecured interbank market was much more favourable than in 2020. As far as borrowers are concerned, there was some increase in concentration due to the events, but it was far less significant than during the previous crisis. At the same time, the polarisation of the market became stronger, as there were more participants who provided liquidity than those who absorbed a considerable amount of liquidity. Despite increased liquidity, the aforementioned strong polarisation may have been related to the higher level and the volatility of interest rates in 2020 .
\end{abstract}

JEL codes: Go1, G15, G21, E44, D85

Keywords: financial market, financial network, financial resilience

1 Ákos Zsolt Bodnár, PhD student, Department of Investments and Corporate Finance, Corvinus University of Budapest. E-mail: akoszsolt.bodnar@uni-corvinus.hu. 


\section{INTRODUCTION}

In this study, I present my findings related to the analysis of the Hungarian unsecured interbank market by comparing the situation before the COVID-19 pandemic with the one after the pandemic. The primary objective of my research is to explore the effect of market uncertainty related to COVID-19 and, in line with this, the active role of monetary policy in the unsecured interbank market. My primary assumption was that increasing uncertainty and the effect of the introduced loan repayment moratorium could result significant decrease in the turnover of the unsecured market segment. However, as my study shows, the turnover increased in 2020 , probably due to the liquidity-providing measures taken by the central bank as well as the favourable situation of domestic banks. I also assumed that the concentration and polarisation of unsecured interbank market increased, exactly like in the previous financial crisis. In order to put my findings into proper context, where necessary, I compared the situation before and after the bankruptcy of Lehman Brothers. In this respect, I relied on the findings published in a study by Berlinger et al. (2011).

In connection with the network of the Hungarian unsecured market, during the financial crisis marked by the bankruptcy of Lehman Brothers, it became obvious that the transaction-based interbank market had changed significantly and fundamentally due to the shock affecting the financial system (Berlinger et al., 2011). The characteristics of the network structure of financial markets and the liquidity of a given market are closely related. Consequently, the structure of the network and the role of the participants within the network may strongly influence the distribution of liquidity. As a result, liquidity cannot run down the system, which may contribute to more volatile quotes even under normal market circumstances: soaring interbank yields in tight liquidity situation are followed by corrections in the case of increased liquidity. Related to the distribution of liquidity and the network structure, I would like to highlight two interrelated phenomena, namely the terms of credit rationing and core periphery structure. Basically, the phenomenon of credit rationing derives from the information asymmetry and moral hazard which are typical of financial markets. As a result, credit markets cannot be brought into balance only by price adjustment. In other words, after a while, the participants of the credit market do not react to changes in market conditions by changing the interest rates, but rather by changing the allocated volume, which manifests itself in the interbank limit systems.

Another important observation characterising the operation of interbank markets is the phenomenon of core periphery. The best description of this phenomenon would be that, within the network, there is a central core, whose members are considered to be safer partners by all or the majority or the participants or a 
clearly identifiable group of the participants. Consequently, everyone likes trading with these core participants. The other side of the phenomenon is a periphery, whose participants do not like trading with each other directly, only through core banks. As a result of this core-periphery group dynamics establish a network structure where core banks can be considered to be key actors in terms of liquidity distribution, on the other hand, they can be considered as systemically important banks (Berlinger et al., 2017). Beyond the main features of the network, the aforementioned two factors can significantly influence the stability and efficiency of the financial system, in other words, they affect how financial markets and the system of financial institutions can resist shocks and perform their functions in a smooth way: the mediation of financial resources, the management of risks and the organisation of payment activities. In conclusion, when studying the network of a specific interbank market, in addition to the volume of liquidity in the system, it is worth examining the market's deeper structural relations which are typical of financial markets.

\section{RESEARCH HISTORY}

In this chapter, I will present the results of previous research, which are relevant to my research, with which I compared my findings and on which I relied when drawing my conclusions. The most important article in research history is considered to be an article by Berlinger et al. (2011), which demonstrated that "volume adjustment was stronger and more long-lasting than price adjustment" by analysing the Hungarian unsecured interbank market before and after the bankruptcy of Lehman Brothers in 2008 (Berlinger et. al., 2011:236). In view of the above, they drew the following conclusion: "Market sentiment cannot be characterised only by the change of total turnover. It is also worth paying attention to which participants are willing to provide loan to which participants and to what extent, i.e. how volume adjustment has taken place" (Berlinger et. al.; 2011; p.236). Gai-Kapadia (2009) came to the same conclusion, claiming that stronger fears of liquidity shortage and counterparty risk led to an increase in risk premium and the collapse of the financing market due to the appreciation and accumulation of liquidity.

The international analyses of financial networks provide extensive documentation about how different network structures react to shocks. In a conventional network model, the analysis by Allen-Gale (2000) shows that, in a network where all the participants are interconnected, the shock resistance of the network is much higher owing to better risk sharing. By contrast, in a network where connectedness is more fragile, sharing the negative effects of shocks is more difficult 
for the less connected banks. Furthermore, Acemoglu et al. (2015) point out in their research that until negative shocks are weak enough, a more connected financial network strengthens financial stability. But there is a point when close interconnection serves as a kind of shock-spreading mechanism, thus leading to a more fragile financial system. Consequently, the same factors which contribute to resistance under certain conditions function as significant sources of systemic risk in other cases. Battiston et al. (2012) also came to the same conclusion, claiming that more connected networks are more resistant to systematic risk for a while due to the possibility of risk sharing. However, beyond a certain point, they observed further, more intense contagion in the case of such networks.

Analysing the network of international banks, Minoiu and Reyes (2013) found that, apart from connectedness, other factors, such as the closeness of the initial shock to the core or the vulnerable node might also have a negative impact on the resistance of the financial system. As a result, core-periphery type networks might show substantial instability under certain circumstances. Related to the core-periphery type financial network, it is worth highlighting the recent research findings by Abduraimova and Nahai-Williamson (2021), who present the coreperiphery type structure. In line with the previous statement, it tends to carry the risk of being infected by liquidity stress; however, this risk is milder in the case of the real network of heterogeneous banks. It is emphasised that the reason for this is that on average, core banks have a higher amount of equity than interbank exposures, which accounts for the regulator's endeavour to allocate special capital buffers to banks which are of primary systemic importance. Such capital buffers allocated to the appropriate points of the system aim to reduce systemic risks and their spreading, thus increasing the resilience of not only the individual participants, but also that of the whole network.

In addition to the above, another important part of the literature review may be the examination of the pandemic's effect on developed financial systems in an international context. In this respect, still relatively few publications are available, but in my opinion, without aiming to give an extensive list, two of these articles are worth mentioning, as they include important findings. Concerning the eight most affected countries by the pandemic, the findings by Rizwan et al. (2020) indicate that, with the exception of China, systematic risk increased in each country in March. Interestingly, this increase flattened in April, which the authors attribute to regulatory and policy interventions. In comparison, Liu et al. (2021) went further and their findings related to the dynamic state of the network also verified the systemic effect of the pandemic. Their results also reveal that, compared to the crisis of 2008 , this shock hit a more resilient financial system, therefore its impact seems to be more moderate. 


\section{INTERBANK TRANSACTION DATA USED FOR THE ANALYSIS}

\subsection{The source of the figures and the description of their term structure}

In order to analyse the unsecured interbank market, I used the database of information which belongs to the scope of information to be supplied to the central bank's information system. Although the requested data are related only to a part of secured interbank transactions as well as fully unsecured interbank transactions, I focused exclusively on unsecured interbank transactions. The database includes the records reported based on the active and passive sides of Hungarian interbank loan and deposit transactions. In view of the above, both parties participating in the transaction have to report each transaction as part of their data reporting obligation. In accordance with the bilateral reporting obligation, each transaction is listed twice in the database, as borrowing on the part of the participant on the active side and as lending on the part of the participant on the passive side. The data used for the analysis were filtered out on the basis of the statistical tables "Ko2" and "K12" specified in the regulation on the scope of information to be supplied to the central bank's information system and on the method and time limits for data supply by the President of the National Bank of Hungary.

In my analyses, figures from the years 2019 and 2020 which are relevant to the topic were highlighted and analysed, as these two periods justify the comparison regarding the question. Therefore, basically, the descriptions of the data as well as the conclusions of the analysis focus on the aforementioned two periods. I consider the year 2019 to be a relevant basis for comparison, as this was the last whole financial year prior to the COVID-19 pandemic which was not or only slightly affected by the measures and effects related to COVID-19. By contrast, as regards the appearance of the virus in Hungary and the relevant measures, 2020 was the year that was fundamentally and wholly affected by the consequences of COVID-19.

Each record contains the date of the report, the GIRO code and the registration number of the data provider and the partner bank, their names, the starting date of the transaction, the date of maturity, the amount of the contract, the lending rate and the fact whether the given transaction was lending or borrowing from the point of view of the reporting bank. When examining maturity, transactions with a maturity of more than one year were filtered out.

Among the transactions, there were overnight $(\mathrm{O} / \mathrm{N})$ transactions with a maturity of 1 day, as well as transactions with a maturity of 1 week, 2 weeks, 1 month, 3 months, 6 months and 12 months and other maturity. The maturity 
structure of the Hungarian unsecured interbank market is similar to the one of international markets. Based on the distribution of the length of different kinds of maturity, more than $80 \%$ of the transactions had overnight maturity in the years 2019 and 2020. In 2019, the share of transactions with a maturity of 1 week was $6.36 \%$, however, it fell to $3.31 \%$ in 2020 . The share of transactions with a maturity of 2 weeks did not change significantly, as it remained $2-3 \%$ in both years. The share of transactions with a maturity of 2 weeks was near $2 \%$ in both years, no significant change occurred here either. The share of transactions with a maturity of 3 and 6 months was below 1\%. By 2020, the turnover and, as a result, the share decreased in both cases. The share of transactions with a maturity of 12 months was below $0.5 \%$ in both years. No substantial change had taken place by 2020 . The share of transactions with other maturity was between $4-5 \%$ in both years. The turnover and share of such transactions increased slightly by 2020 . When further analysing the unsecured interbank market, I did not distinguish between loans with different maturity dates, but I rather assigned each of them to the date of the report irrespective of maturity. The reason for this was the following: I believe that, on the one hand, the entire maturity structure plays an important role in liquidity management, on the other hand, this method provides a fuller picture of the structure of the market.

\section{Figure 1}

The maturity structure of the unsecured interbank market in 2019 and 2020 (1 January 2019 - 31 December 2020)
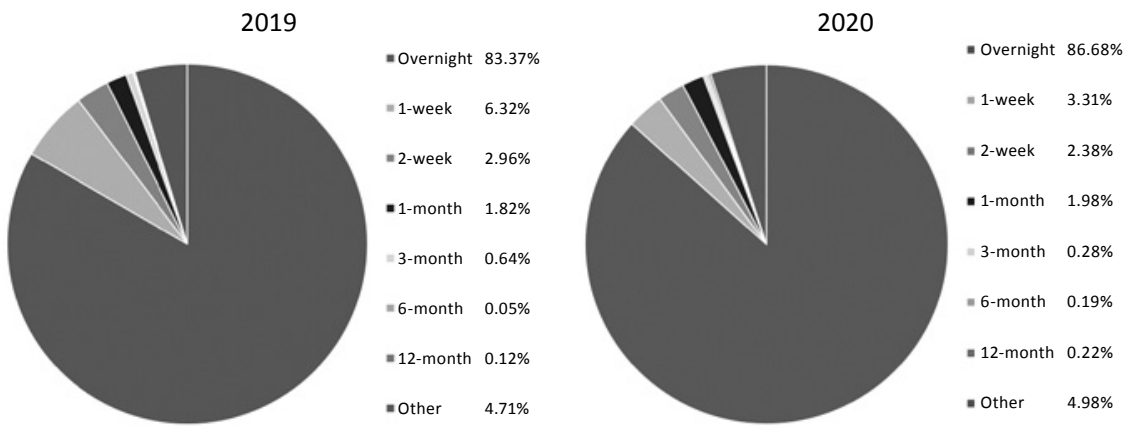

Source: own editing based on MNB data 


\subsection{Turnover and interest}

My next step was to conduct the descriptive statistical analysis of turnover data by daily, weekly and monthly aggregation in order to be able to establish whether there has been any substantial change in turnover and the interest rates if we compare the periods before and after COVID-19. The average and median turnover increased at each aggregation level between 2019 and 2020. Furthermore, the average and median turnover did not differ significantly in either case. The average and median turnover figures were higher in the years 2020 and 2019 than the figures observed by Berlinger et al. (2011) on the data series between 30 December 2002 and 31 March 2009. Then the average daily turnover was HUF 99.9 billion, the average weekly turnover was HUF 484 billion, while the daily median turnover amounted to HUF 97.8 billion and the weekly median turnover amounted to HUF 487.3 billion. At a significance level of $5 \%$, the average and median turnover figures I examined differed significantly only regarding of the weekly aggregation level in 2020. The level of relative standard deviation decreased at each aggregation level between 2019 and 2002. In the period examined by Berlinger et al. (2011), the relative standard deviation at daily and weekly aggregation levels was almost the same as in the year 2019. By 2020, the minimum daily turnover showed a nearly ninefold growth, from HUF 3.6 billion in 2019 to HUF 31.4 billion. Even regarding weekly and monthly aggregation levels, the increase was more than 1.7-fold. By contrast, maximal daily turnover dropped by nearly $10 \%$, while it increased at weekly and monthly aggregation levels. In the period examined by Berlinger et al. (2011), by daily aggregation, the minimum level of turnover was HUF 2.2 billion, which is slightly less than that in 2019. However, at weekly aggregation level, the minimum turnover in 2019 was ten times as high as the minimum turnover between 2002 and 2009.

Table 1

Descriptive statistical analysis of unsecured interbank turnover

\begin{tabular}{lccccccccccccccc}
\hline & \multicolumn{2}{c}{ Average } & \multicolumn{2}{c}{ Median } & \multicolumn{2}{c}{$\begin{array}{c}\text { Standard } \\
\text { deviation }\end{array}$} & \multicolumn{2}{c}{$\begin{array}{c}\text { Relative } \\
\text { deviation }\end{array}$} & \multicolumn{2}{c}{ Minimum } & \multicolumn{2}{c}{ Maximum } \\
& $\mathbf{2 0 1 9}$ & $\mathbf{2 0 2 0}$ & $\mathbf{2 0 1 9}$ & $\mathbf{2 0 2 0}$ & $\mathbf{2 0 1 9}$ & $\mathbf{2 0 2 0}$ & $\mathbf{2 0 1 9}$ & $\mathbf{2 0 2 0}$ & $\mathbf{2 0 1 9}$ & $\mathbf{2 0 2 0}$ & $\mathbf{2 0 1 9}$ & $\mathbf{2 0 2 0}$ \\
\hline Daily & 177.23 & 224.65 & 173.28 & 213.92 & 72.30 & 67.74 & $40.80 \%$ & $30.15 \%$ & 3.60 & 31.40 & 571.47 & 523.78 \\
Weekly & 832.65 & 1076.62 & 837.37 & 1041.51 & 246.40 & 265.23 & $29.59 \%$ & $24.64 \%$ & 263.48 & 470.83 & 523.78 & 1705.14 \\
Monthly & 3677.53 & 4755.07 & 3709.41 & 4646.84 & 727.17 & 710.95 & $19.77 \%$ & $14.95 \%$ & 2246.01 & 3855.78 & 5069.99 & 6628.28
\end{tabular}

Source: own calculation based on MNB data

In the unsecured interbank market, in 2020 , total turnover increased by nearly $30 \%$ compared to 2019. As the volume of liquidity increases, if we examine the change 
in the number of lenders and borrowers, it is observable that, practically, more participants finance fewer participants. Based on the higher number of lending institutions, we may conclude that the borrowers' side is more concentrated. Later in my study, I will deal with an important question: How concentrated was the distribution of allocated liquidity and how was it distributed among the few participants absorbing liquidity?

\section{Figure 2}

The weekly turnover of the unsecured interbank market and the number of lenders and borrowers of loans

(1 January 2019 - 31 December 2020)

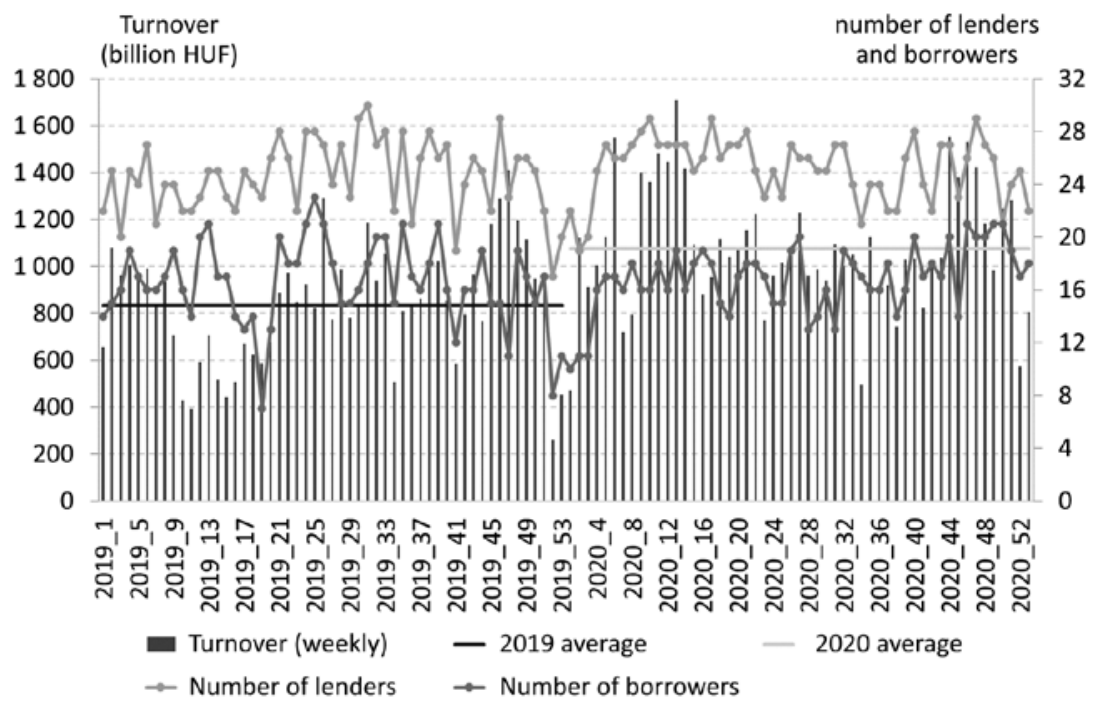

Source: own editing based on MNB data

In order to examine the interest, disregarding maturity, the level of the daily turnover weighted interest can be calculated in the form of time series. Based on the above, it is observable that the first significant spike occurred long after the announcement of the first COVID-19 case. Analysing the figures in detail, the rise of interest rates started already in March. In addition, there was a substantial increase in the interest rates around 20 May. In line with the payment of the value added tax, this increase may tighten the liquidity of the banking system considerably, which may lead to rising interest rates. On the whole, it can be established that the average level of the daily turnover weighted interest was higher and more volatile than in 2019. 


\section{Figure 3}

Turnover weighted interest rate

(1 January 2019 - 31 December 2020)

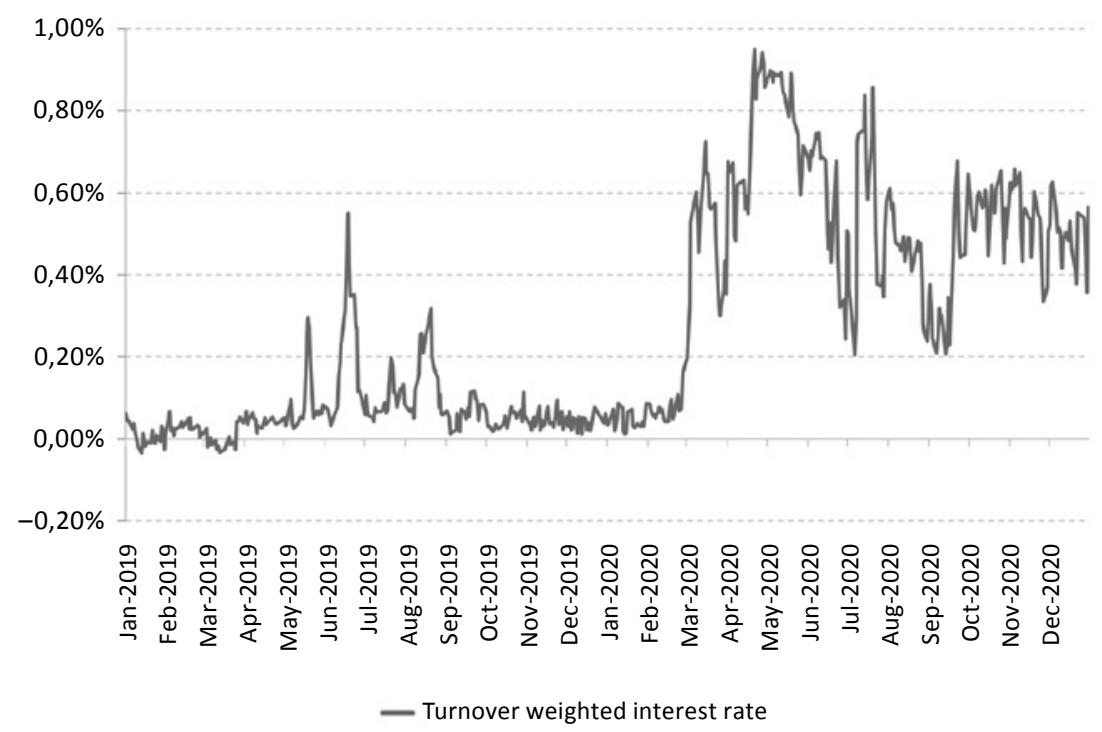

Source: own editing based on MNB data

On the whole, based on the analysis of turnover, its maturity structure and the interest rates, the following can be established: Concurrently with the increase in turnover, no substantial change occurred in the maturity structure. A considerable volume of turnover is still concentrated on transactions with shorter maturity; simultaneously with the increase in turnover, the higher level and volatility of interest rates in 2020 might be partly attributable to the uneven distribution of increased liquidity (and higher demand on the borrowers' side), which may contribute to a higher interest rate level through the increase in partner and liquidity risk. 


\section{FINDINGS}

\subsection{Lending and borrowing by participant}

Based on lending transactions, the market share of the largest participant was $10.92 \%$ in 2019 , which increased to $19.82 \%$ in 2020 . If we put individual participants in order based on their market weight, the market weight of the three and five largest banks increased in both cases from 2019 to 2020.

In this subchapter, I will focus on market polarisation and examine how active individual lenders and borrowers are and whether there are any participants who play a key role on both sides. In diagrams 4 and 5 , lending transaction are marked by a positive sign, while borrowing transactions are marked by a negative sign. If the ratio of a participant's lending and borrowing transactions is 1 or around 1 , the participant's behaviour can be considered to be well-balanced. In 2019, there was only one, while in 2000 , there were two participants in the case of whom the ratio of lending and borrowing transactions was 1 or near 1 . However, it is worth mentioning that the total value of the transactions of such participants was not decisive either. In the light of this, in my view, none of them can be considered as a central participant distributing liquidity. At the same time, they can be regarded as mediating institutions. In 2019, there were 12 banks which appeared only on the liquidity lending or the borrowing side. By 2020, this number dropped to 9. The participants who remained inactive on either side were mainly the same banks over the two years. The remaining participants entered into transactions on both sides, but their weight was slightly more dominant either on the liquidity lending side or on the borrowing side. Based on the results and the diagram, on the borrowing side, I would like to draw attention to participants 3 and 22, whose liquidity demand considerably increased in the period 2019-2020. At the same time, the lending activity of these participants considerably decreased On the lending side, average volume rose, as well. It is also worth mentioning participant 18 , who practically became a primary liquidity lender. In 2020 , the value of the liquidity lent by this participant was more than twice as high as the value that the largest liquidity lender lent in 2019. 
Figure 4

Borrowing and lending transactions by bank, (1 January 2019 - 31 December 2019)

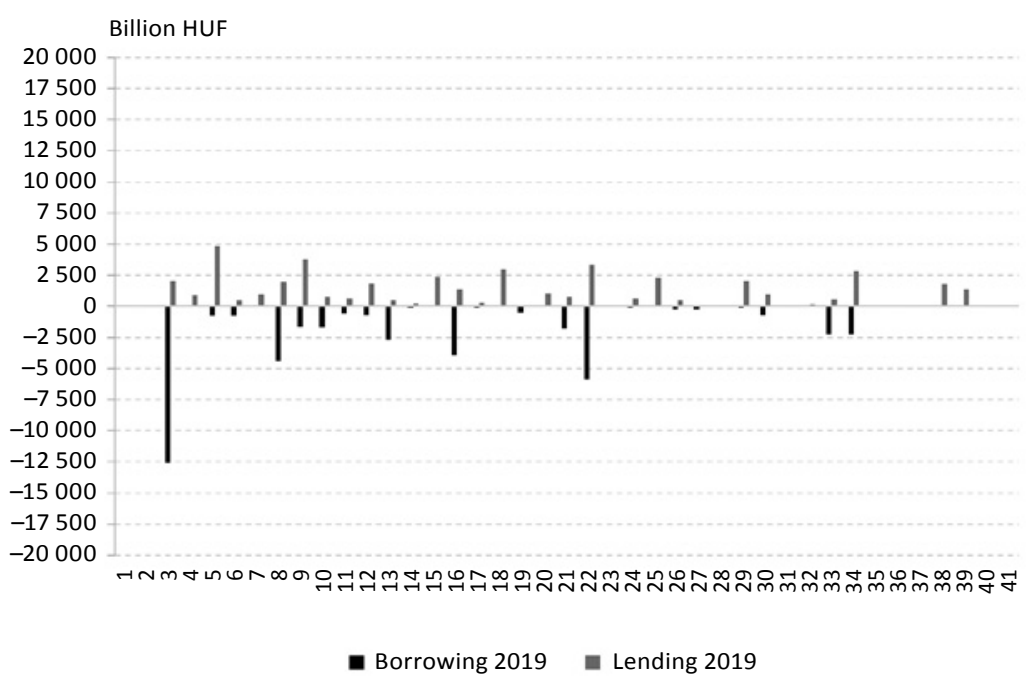

Source: own editing based on MNB data

\section{Figure 5}

Borrowing and lending transactions by bank

(1 January 2020 - 31 December 2020)

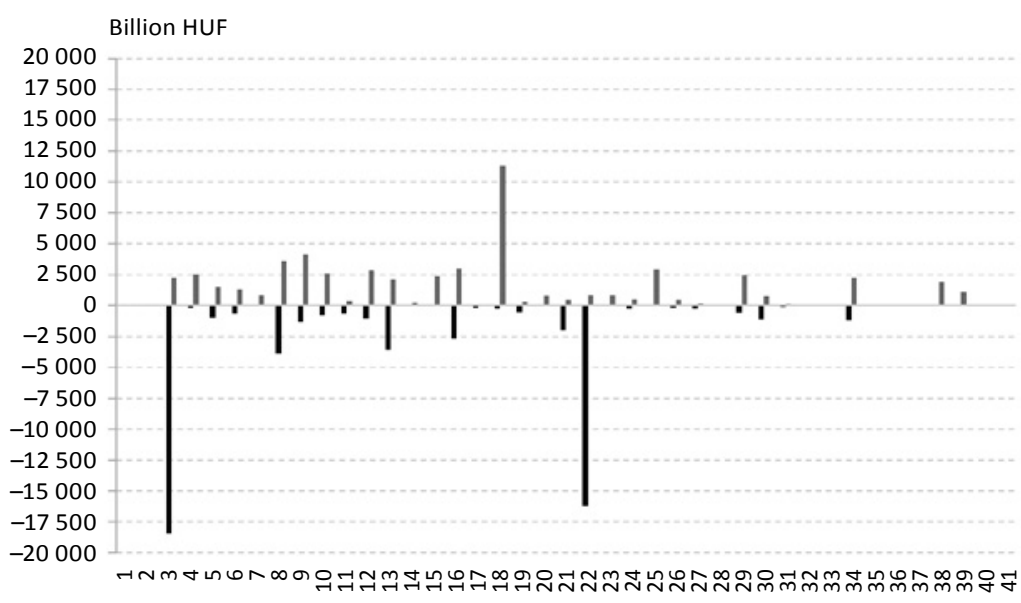

- Borrowing 2020 [ending 2020

Source: own editing based on MNB data 
In conclusion, it can be stated that, although there were participants who clearly provided liquidity and other participants who absorbed free liquidity, this process was more well-balanced and less polarised in 2019. In 2020, the aforementioned roles became stronger and more concentrated, particularly on the side of borrowers. In the light of the above, it can be established that the increased liquidity concentrated in the hands of less borrowers through liquidity lending carried out by several participants. Such market structure is described in an article by Iori et al. (2008). Examining short-term Italian financial markets, the authors came to the conclusion that the system is characterised by a small group of large banks, which are financed by small lenders. Despite increased liquidity, in my opinion, the growing polarisation of the market can be related to the level and volatility of interest rates which became higher after May.

\subsection{The concentration of the unsecured interbank market}

The most important feature of a network is the degree, i.e. the number of connections between a point and other peaks of the network. The degree indicates the connectedness and size of the network. In 2019, the total number of connections (edges) was 260 , which increased to 273 by 2020 . In this chapter, I will show the temporal change of indices suitable for the analysis of concentration. First, it is worth examining the Herfindahl-Hirschmann Index and, as the number of market participants changes by period and market, the indicator should be normalised to ensure comparability. If the value of the indicator is low, competition is supposed to be serious, while a high value suggests increased concentration and a low level of competition. In the case of the HHI, if the value is under $10 \%$, the market is usually considered to be non-concentrated, between $10-18 \%$, it is regarded as being moderately concentrated, while over $18 \%$, it is thought to be highly concentrated. Based on the criterion mentioned above, it can be established that, in spite of the fact that the values of both indicators increased, the unsecured interbank market was still characterised by low concentration on the lenders' side. Having regard to the regulatory provisions and banking limits published since the financial crisis, this finding met my expectations. Practically, banking limits and capital requirements prevent excessive and excessively concentrated exposure. At the same time, as the experience gained from previous market shocks indicates, the market becomes concentrated in an uncertain market situation. It is shown by the effective number, where the decrease of the index indicates the concentration of banking connections. When comparing the concentration index and effective number of the lenders' side with concentration before and after the bankruptcy of the Lehman Brothers, it is observable that the values of the indices moved within a narrow range even in this period (Berlinger et al., 2011). 
If we examine the features of the network on the borrowers' side, as well, the picture is more concentrated. Concentration further increased in 2020 . The market share of the largest borrower grew from $28.48 \%$ in 2019 to $32.25 \%$ in 2020 . All in all, the market shares of the three and five largest borrowing banks also increased by 2020 . On the borrowers' side, the HHI was $10-18 \%$ in 2019 , which refers to a moderately concentrated market. However, in 2020, this value exceeded $18 \%$, which is usually interpreted as a highly concentrated market. At the same time, if we consider the normalised value to be the indicator, it remained under $18 \%$ even in 2020 , despite some increase. Based on the effective number, it can be stated that concentration grew in this case. Following the bankruptcy of Lehman Brothers, the concentration index increased considerably, while the effective number dropped from 12 to 4 (Berlinger et al., 2011), which suggests more significant concentration increase than the change in 2020.

Table 2

\section{Concentration ratios}

\begin{tabular}{lcc}
\hline \multicolumn{3}{c}{ Lending side } \\
\hline \\
\hline Biggest bank market share & $\mathbf{2 0 1 9}$ & $\mathbf{2 0 2 0}$ \\
The biggest three banks market share & $10.92 \%$ & $19.82 \%$ \\
The biggest five banks market shara & $26.74 \%$ & $33.24 \%$ \\
HHI & $39.88 \%$ & $43.62 \%$ \\
HHI & $5.33 \%$ & $7.24 \%$ \\
Effective number & $2.84 \%$ & $4.51 \%$ \\
& 18.74 & 13.82 \\
\hline & Borrowing side & \\
\hline Biggest bank market share & $\mathbf{2 0 1 9}$ & $\mathbf{2 0 2 0}$ \\
The biggest three banks market share & $28.48 \%$ & $32.25 \%$ \\
The biggest five banks market shara & $51.95 \%$ & $67.49 \%$ \\
HHI & $66.92 \%$ & $78.45 \%$ \\
HHI & $13.21 \%$ & $19.96 \%$ \\
Effective number & $10.21 \%$ & $17.46 \%$ \\
\hline
\end{tabular}

Note: I distinguished the normalized HHI index by $\mathrm{HHI}^{*}$.

Source: own calculation and editing based on MNB data

If we examine the trajectory of the concentration index at weekly aggregation level, we can establish two things: On the one hand, on the lenders' side, concentration increased only slightly, and volatility was low. Basically, it can be stated that in 
the 2019-2020 period, the index moved mainly in a well-defined range. In 2019, the value of the index was rather in the middle of the range, while, in 2020, near the top of the range. The value of the index typically broke out upwards from this range only in the last few weeks of the year, after the 4oth week. On the other hand, the borrowers' side was characterised by higher concentration. From the average weekly level of $18 \%$ in 2019 , concentration increased to $22 \%$, which is considered to be strong concentration. Furthermore, based on the weekly values of the index, it is more volatile than the concentration on the lenders' side.

At weekly aggregation level, the higher concentration on the borrowers' side is more conspicuous, indicating that liquidity typically flows from more participants to fewer borrower. This phenomenon became more striking in 2020. By contrast, the slight increase on the side of lending transactions suggests that the mediating role of safer participants might have marginally increased in 2020, which indicates the moderate intensification of risk aversion.

\section{Figure 6}

\section{Concentration of the weekly turnover of lending and borrowing transactions}

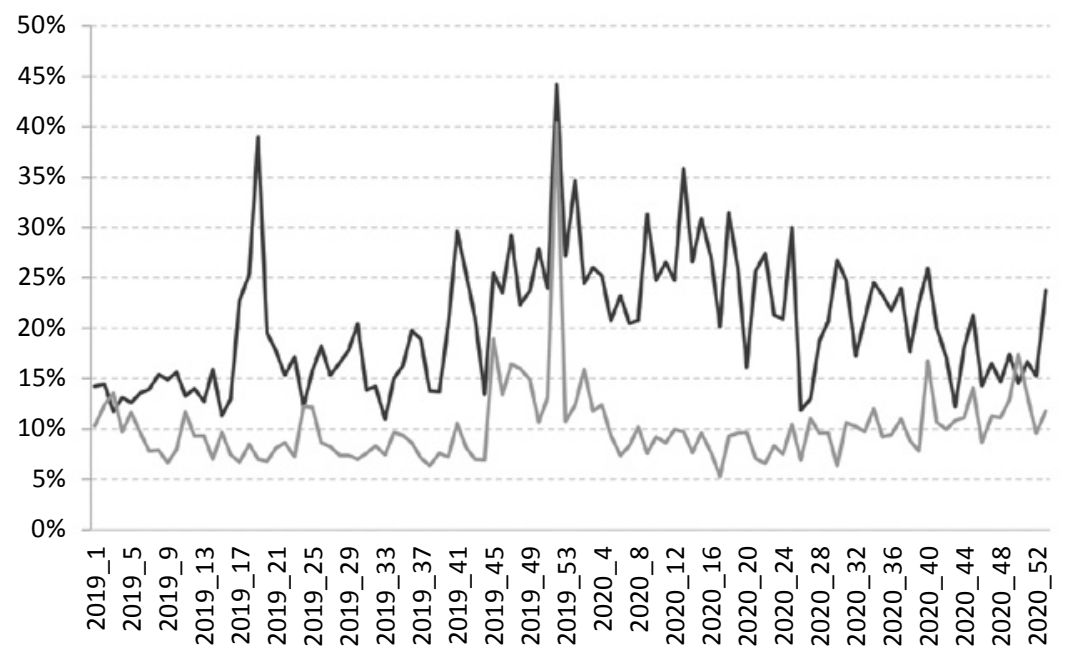

— Borrowong_HHI _ Lending_HHI

Source: own editing based on MNB data

On the whole, it can be stated that the increase of concentration was less significant on the side of lenders than on the side of borrowers. This phenomenon is in line with the observation according to which, in the case of shocks, the gap between the concentration of borrowing and the concentration of lending widens. At the 
same time, it is important to emphasise that the rise of concentration, particularly on the borrowers' side was less sharp than the rise in 2008 (Berlinger et al., 2011).

\section{SUMMARY}

I would summarise the findings of my research by listing the possible reasons which, in my opinion, contributed to the fact that the negative shocks related to the COVID-19 pandemic hit the domestic banking system in a favourable shock-resistant state. As a result, we can experience that, as opposed to previous crises, the arising risks are managed more smoothly due to the macroprudential framework established over the past few years, fast intervention by the central bank and the strong profitability in recent years. In my view, such factors play a key role in, for example, creating a more favourable picture in the unsecured interbank market in the event of a shock.

The first factor includes the measures taken by the National Bank of Hungary, which can be divided into two groups: on the one hand, measures taken before the COVID-19 pandemic, on the other hand, active participation following the appearance of the COVID-19 pandemic in 2020. The measures of recent years include supportive monetary policy environment. Within this category, it is worth mentioning the increase of the liquidity of the banking system as well as the BUBOR reform. After the appearance of the COVID-19 pandemic, the Hungarian central bank took an active role in the management of the crisis. Regarding the increase of liquidity, without aiming to give an extensive list, I would like to highlight some measures by the central bank which I consider to be the most important (MNB, 2020a). In addition to tenders providing 1-, 3-, 6and 12-month HUF liquidity, the activation of liquidity provision with a maturity of 1 week ensured the appropriate level of liquidity in the banking system and smoothed liquidity processes. Furthermore, in order to increase the central bank liquidity that can be potentially reached by the banks, the National Bank of Hungary expanded the scope of collateral with corporate loans. Consequently, the volume of assets that was available as collateral to banks increased by HUF 2600 billion at reception value. On the other hand, the central bank introduced an additional, fixed-interest secured loan facility with a maturity of 3, 6 and 12 months, as well as of 3 and 5 years. In addition to fixed-interest, the central bank also provided unlimited liquidity with these loans. Moreover, the central bank provided exemption from the non-performance of reserve obligation. Due to this move, the freely available liquidity of the banking system increased by nearly HUF 250 billion. Finally, the central bank launched an asset purchase programme, in the framework of which the central bank purchased government securities in the 
secondary market, and it also restarted its mortgage bond purchase programme to increase the funds available to the banking system in the long term.

A common feature of the measures in the list is that they supported the appropriate liquidity of the banking system, and in my opinion, they also contributed to the maintenance of the confidence of the participants of the banking system. As far as my study is concerned, I would like to emphasise that as a result of the liquidityproviding measures listed above, the turnover increased in the unsecured market in 2020. In other words, a part of the increased liquidity was used in this market.

Secondly, it is worth mentioning that, owing to their prosperous operation prior to the crisis and regulatory developments, the banks had and still have appropriate capital buffer and considerable liquidity reserves. Based on stress tests conducted by the regulator, the majority of banks would meet the regulator's expectations on liquidity and capital situation even in the case of an unexpectedly severe scenario (MNB, 202ob). In the light of the above, the banks' cooperation with the central bank as well as their well-balanced operation might have contributed to the fact that the banking system was better prepared and more resistant to the negative effects in 2020.

The third factor that may seriously determine the research topics of the following years is hidden in the nature of the economic crisis related to the pandemic. It is already obvious that this crisis differs from previous crises in terms of its nature and consequences. It is interesting what kind of medium- and long-term effects it will have and how they will affect the financial system. Currently, we believe that this circle of institutions properly resists to the aforementioned challenges.

\section{REFERENCES}

Abduraimova, Kumushoy - Nahai-Williamson, Paul (2021): Solvency distress contagion risk: network structure, bank heterogeneity and systemic resilience. Bank of England Staff Working Paper, 909. https://papers.ssrn.com/sol3/papers.cfm?abstract_id=3796283.

Acemoglu, Daron - Ozdaglar, Asuman - Tahbaz-Salehi, Alireza (2015): Systemic Risk and Stability in Financial Networks. American Economic Review, 105(2), 564-608. DOI: https://doi. org/10.3386/w18727.

Allen, Franklin - Gale, Douglas (2000): Financial contagion. Journal of Political Economy, 108(1), DOI: https://doi.org/10.1086/262109.

Battiston, Stefano - Delli Gatti, Domenico - Gallegati, Mauro - Greenwald, Bruce STIGLITZ, JosEPH E. (2012): Liaisons dangereuses: Increasing connectivity, risk sharing,and systemic risk. Journal of Economic Dynamics and Control, 36(8), 1121-1141. DOI: https://doi. org/10.1016/j.jedc.2012.04.001.

Berlinger Edina - Daróczi Gergely - Dömötör Barbara - Vadász Tamás (2017): Pénzügyi hálózatok mag-periféria szerkezete. A magyar bankközi fedezetlen hitelek piaca, 2003-2012 [The Core-Periphery Structure of Financial Networks. The Hungarian Unsecured Interbank 
Loan Market, 2003-2012]. Közgazdasági Szemle, Vol. LXIV. November, 1160-1185. DOI: https:// doi.org/10.18414/ksz.2017.11.116o.

Berlinger Edina - Michaletzky Márton - Szenes Márk (2011): A fedezetlen bankközi forintpiac hálózati dinamikájának vizsgálata a likviditási válság előtt és után . [Analysis of the Dynamics of the Unsecured Interbank Hungarian Forint Market Before and After the Liquidity Crisis] Közgazdasági Szemle, Vol. LVIII. March, 229-252.

Gai, Prasanna - Kapadia, Sujit (2009): Liquidity Hoarding, Network Externalities, and Interbank Market Collapse. https://crawford.anu.edu.au/pdf/ajrc/2010/conferences/financial_regulation_and_structure/prasanna_gai_paper_2.pdf.

Iori, Giulia - De Masi, Giulia - Precup, Ovidiu Vasile - Giampaolo Gabbi - Caldarelli, GUIDo (2008): A network analysis of the Italian overnight money market. Journal of Economic Dynamics \& Control, 32, 259-278. DOI: https://doi.org/10.2139/ssrn.841607.

Liu, Shaowen - Caporin, Massimiliano - Paterlini, Sandra (2021): Dynamic network analysis of North American financial institutions. Finance Research Letters. DOI: https://doi. org/10.1016/j.frl.2021.101921.

Minoiu, Camelia - Reyes, Javier A. (2013): A network analysis of global banking: 1978-2010. Journal of Financial Stability, 9, 168-184. DOI: https://doi.org/10.2139/ssrn.1903966.

MNB (2020a): A Magyar Nemzeti Bank monetáris politikai eszköztára a Covid-19-válság időszakában: likviditás, biztonság, rugalmasság [The Monetary Policy Toolkit of the National Bank of Hungary During the COVID-19 Crisis: Liquidity, Security, Resilience]. https://www. mnb.hu/letoltes/jegybanki-eszkoztar-2020-covid19.pdf.

MNB (2020b): Pénzügyi stabilitási jelentés. 2020. november [Financial Stability Report, 2020 November]. https://www.mnb.hu/letoltes/penzugyi-stabilitasi-jelentes-2020-november.pdf.

Rizwan, Muhammad Suhail - Ahmad, Ghufran - Ashraf, Dawood (2020): Systemic risks: The impact of COVID-19. Finance Research Letters, 36. DOI: https://doi.org/10.1016/j.frl.2020.101682. 